\title{
Interrogating the Projection of Fiction-as-Facts: Appropriation of the Spaces of Caste in Sindhi Short Stories and in Everyday Politics in Pakistan
}

\author{
Ghulam Hussain \\ Web of Science ResearcherID: $\underline{\text { P-7210-2018 }}$ \\ ORCID $\underline{0000-0002-9538-1840}$
}

\begin{abstract}
Ghulam Hussain is a doctoral fellow at the Department of Anthropology, Quaid-i-Azam University, Islamabad. He can be accessed online at mahesarg@gmail.com.
\end{abstract}

\begin{abstract}
This paper is an attempt to understand the intersected nature of the appropriation of the spaces, events and acts of oppressed castes (and gender) in the 'Progressive' Sindhi short stories and in everyday politics. I specifically discuss the three popular short stories that are projected as having exceptional emancipatory potential for the Dalits and women. Mounting the Ambedkarian critique of the Progressive writers' political agenda premised on Sindhi nationalism, I interrogate the short-story writer's caste location and the content of short stories having empirical consequences for Dalit (women) in everyday life. I contend that even these seemingly pro-Dalit and pro-woman fictional narratives and their empirical interpretations, do not pass the test of Ambedkarian epistemology as they do not show any commitment to the annihilation of caste/casteism and gender disparities, and rather suggest objectification of Dalit bodies instead of emancipation through Dalit agency. Although the appropriated projection of facts in fiction may temporarily invoke Ashrafia morality to confront casteism, yet they are largely apologetic in their tenor, and eventually turn out to be counterproductive. The stories, being primarily fashioned in Ashrafia-Savarna narrative, facilitate the Ashrafia-Savarna elite to
\end{abstract}


appropriate heroes, histories or events and spaces of Dalits to sustain their social domination over Dalits. Therefore, I conclude that the narrative(s) emergent of these stories, and allied sociopolitical practices have both emancipatory as well as hegemonoic and counter-hegemonic aspects depending upon who patronises whom. Yet, looking holistically, they do not have the requisite emancipatory potential for the Dalits, and at best offer Dalits a false pride and a token sympathy and compassion.

Keywords: Casteism, Ashrafia-Savarna Patriarchy, Appropriation of Dalit Spaces, Hegemony, Progressive Literature, Everyday Politics of Fiction.

\section{The Introduction}

'Sindhi language' is the cultural universal in postcolonial Sindh ${ }^{1}$, in which bulk of the local literature is published in the form of books, magazines, newspapers ${ }^{2}$. Inspired by the international modern progressive movement in politics and literature during the 1950s and 1960s, the Sindhi writers identified themselves as 'Taraki-Pasand' (Progressive) (see Malkani, 1993; Hussain, 1997; Memon, 2002; Siraj, 2009; Paleejo, 2012; Paleejo, 2016; Chandio, 2016).

${ }^{1}$ Sindh is a province of Pakistan having about 47.89 million population (Source: Bureau of Census Pakistan), and is located at $25.8943^{\circ} \mathrm{N}, 68.5247^{\circ} \mathrm{E}$ coordinates on the world map.

${ }^{2}$ To have an idea of the literature being produced in Sindhi language, see the following online libraries and Publishing houses:

1. Sindhi Salamat.URL: https://books.sindhsalamat.com/. (accessed on June 6, 2019)

2. Sindhi Adabi Borad. URL: http://www.sindhiadabiboard.org/Index.html (accessed June 6, 2019)

3. Sindhi Language Authority. URL: http://www.library.sindhila.org/home.(accessed on June 6, 2019)

4. Roshini Publications.URL: https://www.roshnipublication.com/

5. Sindhika Academy. URL: http://www.sindhica.net/English.htm. (accessed on June 6, 2019) 
'Progressiveness' is explained by Dr. Ghafoor Memon, a Sindhi literary critic, as 'an attitude, perspective and the movement that has been there in every era' such as during the Greek period 'when Socrates rebelled against the traditions of his time and gave forth a new philosophy, and stood for truth.' (Memon, 2002, p.279, or when European populace began resisting against feudalism, religiosity and fanaticism during French and October (socialist) revolution, and in process, rationality and scientific thinking symbolic of 'Progressive' attitudes, emerged (Memon, 2002, p.279).

In this paper, I critique the casteist aspects of the Progressive literary-political terrain as it manifests from the projection of short stories in everyday politics by the Progressives, by the Ashrafia elite and by Dalits to create space for the Dalit ${ }^{3}$. I contend that despite occasional anticaste and anti-patriarchal narration in a few short stories, the Progressives' primarily frame these issues in a manner so that it could correspond with their agenda of 'political Sufism' (see Hussain, 2019a), facilitate the appropriation of the spaces, events or histories and heroes of Dalits, thereby undermining the life-world and worldview of Dalits.

It gradually revealed to me during my fieldwork in 2016 in lower Sindh that despite the fact that Dalit issues were undermined coupled with the fact that unlike Sayeds and Sammat castes, Sindhi language was not the mother tongue of most of the Dalit communities ${ }^{4}$, Dalits

\footnotetext{
${ }^{3}$ Also locally known as 'Darawar' and Scheduled Castes, there live estimated 2-6 million Dalits. Kolhi, Bheel, Meghwar are three major Dalit castes that inhabit in Sindh (see Hussain, 2019).

${ }^{4}$ Dalit worldview and the fundamental conceptions of self and society are essentially framed, for instance, in Gujarati or Parakari, Dhatki or Rajasathani and Marvari or Kacthi languages. Therefore, they cannot express their deepest emotions and experiences in Sindhi language which
} 
were greatly influenced and impressed by the popular literature produced by that Progressive class. This shows not only the level of 'hegemonic' (see Gramsci, 1971; Hussain, 2019b) influence of Ashrafia ${ }^{5}$-Savarna class over Dalits, but also the epistemic freedom of the Ashrafia class to construct the narrative of their choice out of short stories, novels and poetry that they produce thereby relativizing Dalit subordination and influencing the Dalit's self-perception. For instance, I observed during my fieldwork in 2016, that when the 'Dalit' question was invoked using the 'Dalit' and the 'Scheduled Castes' identity markers by the Dalit activists, the Sindhi nationalists and most of the contemporary Sindhi progressive writers and their followers attempted to reject Dalit activists' reidentification and their claims. They denied and relativized Dalit exclusion, and discouraged the Dalit activists to frame Dalit exclusion in terms of castebased discrimination.

With the given structural discrepancies in perspective, I explain the epistemological, ideological and the political reasons as regards why caste and Dalit exclusion are not the important factors of analysis in the Progressive Sindhi short stories. I critique the casteist aspects of this Sufi nationalist literary terrain that has been popularized by Ashrafia-Savarna class during the last six decades. I specifically interrogate the appropriation of Dalit cause, Dalit spaces and Dalit identities in Sindhi short stories written and interpreted by the Progressives and consumed by the Dalits of Sindh. To that end, I discuss three Sindhi short stories as the typical cases of the

they have adopted as the medium of communication under the 'hegemonic' influence of Ashrafia-Savarna culture.

${ }^{5}$ Ashrafia class (i.e. Sayeds or the descendants of the Prophet Muhammad, and the castes claiming to be of Arab and Central Asian descent. (see Hussain, 2019; Ahmad, 2003; Kazuo, 2004). 
Progressives' variedly constructed and interpreted literary pieces, and validate my analysis further by adding a few but key ethnographic insights. To shortlist the stories, I adopted the method of asking some 30 notable Sindhi literary scholars and the Progressive-mined readers to identify the short stories that may help interrogate Sayedism and Dalit exclusion along with the oppression of Dalit women. After a month's exploration assisted by the Dalit activists, I could only gather a few short stories that seemed to explicitly intersect caste along with religion, class and gender. I then analyzed three of them, namely 'Dust of Earth and Stars of Sky' by Amar $\mathrm{Jaleel}^{6}$ that related to the oppression of Dalit (women); 'Infidel' by Naseem Kharal that brought into focus the trans-religious dimension of untouchability as it affects the Dalit's decisions to convert to Islam; and 'Prisoner of Karoonjhar' by Ali Baba which is based on the postcolonial reconstruction of the $18^{\text {th }}$ century anticolonial event related to the supposed bravery of Rooplo Kolhi, a Dalit hero.

\section{Theoretical Framework}

The key factor that I analyze in this paper is the appropriation of Dalit spaces and identities by the Progressive short story writers and by the Progressive Ashrafia and non-Ashrafia (Dalitbahujan) interpreters. The purpose is to see if the historical narratives and their fictionalized characters allow Ashrafia intrusion in the in Dalit spaces, and if in any way helps achieve the egalitarian purpose of caste-parity, social inclusion and justice ( see for instance, Sayed, 1952; Sayed, 1974; Sayed, 2013), and hence promoting the tendency to 'Ashrafize' (Kazuo, 2004; Buehler,2012).

\footnotetext{
${ }^{6}$ Amar Jaleel received Kamal-i-Fun award, which is the highest award in Pakistan in the field of literature. Apart from that he also received Pride of Performance (Pakistan) and Akhil Bharat Sindhi Sahat Sabha National Award of India.
} 
Although this way of critiquing casteism from the Dalitbahujan or Ambedkarian perspective ( see Ambedkar, 1944; 2014 (1991); Ilaiah, 2010; Guru \& Sarukai, 2012; Hussain, 2018, Hussain, 2019a; Hussain, 2019b) is line with the subaltern, critical and the Marxist theories of literary criticism (see Behdad, 2011; Damrosch, 2009; Eagleton, 2002), yet it also mounts the critique of both the Marxist and the subaltern or the postcolonial approaches that did not bring caste(ism), as argued by Ambedkarites, into due consideration (see Kumar, 2016a; Kumar, 2016b). Ambedkarism demands the explicit anti-caste stance from the literary critics of the societies based on caste discrimination (see Guru, 2011a;2011b; Kumar, 2018).

The Ambedkarian critique of 'untouchability' against Dalits, however, should be differentiated from the Gandhian critique of 'untouchable' treatment of Dalits. In his critique of the Hindi and Urdu short stories of Munshi Premchand, follower of Gandhi, Ghulam Rabbani (2016) writes:

The Harijan lives like dead soul, having accepted all the exploitation and atrocities as their destiny. They might develop a defiant attitude against these injustices but it remains confined to their minds. On the contrary, Ambedkar's Dalit is audacious, courageous and infused with zeal and zest to fight against exploitation and live with dignity. His rebel doesn't just imagine being one but steps into the real world.

Looking from this Ambedkarian perspective, in this paper, I critique the content, quality, and quantity of the short stories written by Progressive Sindhi writers.

Informed consent was obtained from all participants. All procedures performed in this study involving human participants were in accordance with the ethical guidelines recommended by the Ethical Review Committee of the Department of Anthropology, Quaid-i-Azam University, 
Islamabad. The permission was sought, where required, from the concerned persons to reproduce any picture, graph, table or piece of information.

\section{Situating Short Stories in Sindhi Progressive Literature}

The Progressives boast of, and probably rightly so, that both in terms of quantity and as the instrument of political awareness, after Urdu, Sindhi language has the second richest stock of literature in Pakistan (Paleejo, 2016, p.11) Since the Sindhi Ashrafia-Savarna elite has dominated the literary-political domain for centuries, most of the prominent writers, poets and the scribes from Qazi Kazan (1463-1551, the first known poet) to Shah Abdul Karim, Sachal Sarmast and Shah Inayat hailed from Ashrafia castes. The same holds true of most of the Sindhi Short story writes. They depart from their predecessors in that they qualify their Sufism with the Western modern, romantic, Marxist and the nationalist ideas (see Memon, 2002, p.28; Jaleel, 1998; Jaleel, 2007; Shah, 2007a; Shah, 2007b; Jaleel, 2012). The common themes of the short story writers have been to condemn wadera culture (feudalism) and Mullah (the religious cleric. For instance, feudalism is critiqued in stories such as in 'Billu Dada' and 'Kutte jo maut' by Ayaz Qadri; 'Munh Karo’ and 'Pashoo Pasha' by Jamal Abro; 'Sheedo Dharel' by Ghulam Rabani Agro. Similarly, religious fanaticism and extremis is busted in stories such as, 'Maan Insaan Ahiyan' by Ayaz Qadri, and 'Aman Maan School na Wendus' by Hafeez Shaikh (see also Memon, 2002, p 314-15). These stories, however, often give an impression that casteism, particularly Dalit exclusion is a normative phenomenon about which agents of social and political change need not to worry about. For instance, in the story, Pishu Pasha ( possibly a Sammat-Baloch character depicted as the socialist revolutionary), Jamal Abro (2015) draws the peripherial depiction of the normative status of 'Chuhra' caste while showing the daring act of Pishu to drink water in the glass specified for the landlord. He writes: 
Once, [Pishu] passed by guest of house Raes Gul Khan. He was dying of thirst. Withouth caring for consequences, he entered the guest house and grabbed the glass of Raes Gul Khan. All present on the scene tried to stop him, 'Nope, Nope!;

But, by that time this gentleman had drunk two-three glasses of water. Putting down the glass, [Pishu] said 'Brother why, was that glass of any Chuhra?"

(Abro, 2015)

This portrayal of Chuhra as the excluded, the projection of Pishu (upper castes) as the new 'untouchable, and the projection of socialist confrontation lying between the protagonists of the privileged castes, one dominating the other, may not be vouchsafed by the Ambedkarites.

The Progressives have also written a few remarkable short stories that expose the exploitative character of Sayeds. For instance, Jamal Abro's (2015) story 'Shah Jo Pharr' first published in 1959 directly confronts Sayedism, in which the discriminatory differentiation between Sayed and Ummati (Subject Muslim) is depicted (Abro, 1958, p. 325), and in 'Mau Ji Jholi' an Ashrafia class woman is depicted as embracing a Bhangi (Dalit) child (Abro, 1958, p.326). Similarly, Noorul Huda Shah ${ }^{7}$, a Sayed woman herself, has written a few anti-Sayed short stories that indirectly defend the Dalitbahujan right to equal social treatment (Shah, 2007 a; Shah,, 2007b; Memon, 2002 ). Her short story 'Dozkhi' also brings to light the racism of Sindhi people against Sheedi caste of the Black African descent (Shah, 2007).

\footnotetext{
${ }^{7}$ Noorul Huda Shah is one of the most celebrated Sindhi short story writer, Pakistani playwright and former caretaker provincial minister of Sindh Government in 2013. See: https://www.dawn.com/news/799025 (accessed June 6, 2019)
} 
One highly critical short story 'Secrets of Mansion" ${ }^{8}$ by Manik depicts the nexus between patriarchy and Sayedism. In it, the writer shows how strict caste endogamy and patriarchy prevalent in Sayed families creates conditions of celibacy for women and sexual relations outside of wedlock. A Progressive activist told that Manik was abused, ridiculed and even socially boycotted to the limits to eventually commit suicide ${ }^{9}$. Some of the leading Sindhi Progressive writers vehemently criticized him for his exposition of patriarchy embedded in Sayedism. Shaukat Shoro, a Progressive short story writer opined that, 'Manik is merciless, murdering and oppressive writer. Amongst the comity of Sindhi writers, he stands apart and alone, to whom the most privileged Sindhi literary writers do not accept, while the readers, after having avidly read, begin abusing him' (Manik, 1992). This shows the level of the critique that Manik had mounted, and because of which he was deliberately alienated from the mainstream Progressive circles as he did not even explicitly subscribed to Sufi nationalist narrative and delved in existentialism.

Notwithstanding her extraordinary self-critical and anti-Sayed stance and the feminist inclinations, these selective Progressive writers do not draw the clear line between the level of exploitation and humiliation of the Sayed women and the Dalit women, or the Dalit Sindhi and Savarana Hindu. In fact, the Progressives applied their own standards of gender (dis)parity when it served their purpose. For instance, the two stories 'Mubarakhoon' and 'Sagar Je

\footnotetext{
${ }^{8}$ See "Haveli JaaRaaz, (1967) first published in Sindhi digest 'Shuni'.

${ }^{9}$ Manik's wife, however, maintains that Manik died of heart attack. Some of Manik's close friends argue that although Manik was bitterly criticized for his writings, particular for his purportedly 'sexually explicit' depiction of patriarchal social reality and Sayedism, his circumstance of death has not much to do with it.
} 
Laharun $T e$ ' that show Sindhi women rebelling against patriarchy and the forced marriage, are not held in good light by the Progressives such as Rasool Bux Paleejo who considers it the prime illustrations of 'negative' rebellion (see Memon, 2002, p.319). Moreover, the scathing criticism that a few of these anti-Sayed Ashrafia class writers faced is also an indicator of the lack of 'shared space' for the Dalit intellectuals (mostly identified as Hindus as well) to expose Sayedism. Hence, although their ideological and discursive trajectory was highly critical from the Ashrafia egalitarian or the Sufi nationalist perspective, it did not seem to qualify for the wholehearted approval by the Dalit-feminist intellectuals and or the Ambedkarites (see for instance, Guru, 1995; Lata, 2015; Kundu, 2017; Sripathi, 2017; Velaskar, 2012; Margaret, 2012). In the sections that follow, I would further explain through Ambedkarian perspective, the excerpts from three popular short stories by Amar Jaleel, Naseem Kharal and Ali Baba as regards how they (mis)fit as the anti-caste and anit-patriarchal Progressives.

\section{Dust of Earth and Stars of Sky}

The short story 'Dust of Earth and Stars of Sky' (Dharti ji Dhoor, Asman jaa Taara) by Amar Jaleel arouses the compassion for Bali, a Bheel (Dalit) woman who had been seduced and raped by Shahu, a Sayed patriarch. To give the reader an idea of the ideological lens of the writer to the problem of casteism, I am quoting below the translation of selective sections of the story. [Depicts the beauty and social vulnerability of a Hindu Dalit woman]

The emotions of the youthful age cannot be controlled by the systems of caste or religion. The people of Rohri town could not escape the gorgeous youthful spark of Bali. Her startling beautiful body could barely be hid under her tattered clothes (pg. 68-69).

[A dialogue between Shahu and Bali]

'And Sisters? '['What did they do?' asked Shahu] 
'They were harlots' (p74)

$[\ldots]$

'The eldest eloped with a rascal Punjabi ....and he engaged her in prostitution'

'The younger one eloped with a Baloch to Shikarpur'....'A few days later there was corpse of my sister lying on the river bank'. (p.75)

[Depicts people's belief in Sayedism...Two aged school teacher in a dialogue with Shahu] 'Junior Shah! Hope you are fine’ [Teachers greeted Shahu while he having whisky] 'Fine, need your prayers' Shahu replied coldly.

'Why are you making we ummatis[ subjects of yours] sinner'. One of the teacher even pleaded before him, saying, 'We solely rely on you for our wellbeing here and in the hereafter'.

Shahu remained utter disinterred towards teacher's pleadings. (p. 80)

[Shahu seducing drunken Bali]

[Bali] 'I am not even a Muslim'

[Shahu], 'I am Sayed, who truly deserves to be in paradise'. He dragged her to herself,

'In Islam the greatest of bounty is to convert any non-Muslim to Islam. I will make you Muslim'.

... 'I will marry you and teach you how to behave in Ashrafia family'. ... 'Leave knitting nets.'

....Bali gradually slid her face on the breast of Shahu, and said 'I will leave knitting nets'. (p.84-85)

[Sayedism reflects when Shahu does not accept Bali and the child girl begotten of him] 
[Shahu's friend Siraj] 'Uncountable children of the Ashrafia are begotten and brought up this way among the Bheel'. Siraj tried to console Shahu, 'Why do you worry so much'. 'I am Sayed Siraj' Shahu rebutted in hard accent. (p.88)

'Humiliation terrifies the honorable. Not to the worthless Bheel women who does not know about what dignity is'. (p.89)

[Shahu' yells at Bali]

'You, the despicable, lower caste, you are a worthless Bheel'. Shahu grabbed her from her plait and said, 'and do you know, I am Sayed, Sayed am I'. (p.93)

'We do not even let our ummatis [Muslim subjects] to get so close to us, and this infidel Bheel dreams of marrying a Sayed'. (p.94)

[Shahu goes to kill Bali's newborn child daughter]

He was consoling himself that he was killing a newborn daughter in the name of God. To save a Sayed child from wandering among the Bheels. In the afterlife, God will give him his due reward. In case it did not happen as planned, then at least he had that genealogical capital of being Sayed to intercede before God. (p.101)

(Jameel, 1998, 68-103)

The story depicts tragic socioeconomic and personal vulnerability of Dalit women due to which they are often raped and made pregnant by Ashrafia men. From the Ambedkarian perspective the story has great a emancipatory value. It brings into relief the Dalit women's oppression vis-à-vis Sayed. The writer enters into the minds of both the oppressor and the oppressed and brings out the caste-based arrogance of the Sayed, and the haplessness and humiliation of the Dalit woman. The story, in a way, imputes Asharfia castes, particularly Sayeds and Muslims of committing this structural injustice to the Dalit (women). In a highly pro-Sayed society in which even the 
Progressive writers are reluctant to speak against Sayeds, the writer has shown a great dare to impute Sayeds, the risk that no Dalit intellectual can afford to take. Dr. Ghafoor Memon writes in his review of the story:

There is a specific nature of the honor and the respect of Sayeds in Sindh, whereby people confer upon them the status of Murshid (spiritual leaders), and consider them as the continuation of Prophet Muhammad's progeny, and to themselves as 'ummatis' (social subjects of Sayeds) thus assigning themselves lower status. No doubt, the respect for Sayeds in its own way is justified, but there have been Sayeds in history who has taken an undue advantage of that status. After the coming of modern progressive wave, the thinking has evolved not to discriminate on the caste and race.

(Memon, 2002, p. 259)

The Ambedkarites may not accept that apology and the conferring of credit to Ashrafia-laden Progressive class, and may raise certain fundamental concerns. For instance, the writer does not suggest any escape for the Dalits out of that situation thereby leaving them in the depressed state. Bali, a Dali woman, is shown to give birth to the child, but her psychological strength is not depicted as to surpass the social and political prowess of his Sayed seducer. Fearing that her child could be killed by the Sayed(s), she even hides the act of seduction and the fact that Sayed was a father of her child. Although this exemplifies the caste-based and religion-based structural violence of high order and the counter-resistance by the individual Dalit woman, the Ambedkarites may have liked to take it further into the collective domain of resistance to enthuse the spirit of collective resistance. Hence, the story ends up abruptly leaving the Ashrafia reader in a state of compassion for Dalits, and to Dalits in a state of self-pity. 
Although in many other short stories and public statements, Amar Jaleel certainly seems to stand against Sayeds and Pirs in so far as his own caste privilege (dis)allows him to be, yet the frequency and the number of such stories that depict Dalit oppression in relation to Sayedism is comparatively very low. This story, therefore, is the only one of its kind written by him that projects Dalit-women's oppression, but that too does not takes the reader towards Dalit emancipation. This fact then complicates the writer's personal life at the level of commitment to eradicate caste discrimination or to emancipate Dalits. Playing the role of the Dalit liberator, Amar Jaleel, in fact, defines the Ashrafia definition of 'Dalit women's oppression. Colored in Sufi nationalist ideology of interfaith harmony, Jaleel condescends to take Sayed Patriarchy and misogyny to the task that does not help invoke Dalit women's emancipation as the Dalit women's depiction of her naivety and sexual vulnerability to Ashrafia patriarchy are not sufficiently counterpoised with the Dalits or Dalit women's agency to strive for emancipation. Resultantly, the Ashrafia reader of the story instead feeling remorse or shame on his or her patriarchy is led to enjoy the Dalit woman's sexuality and body.

Moreover, since the story does not specifically takes the anti-caste stance and wavers in its emphasis on Hindu-Muslim, Sayed-non-Sayed, Dalit-Sayed, women-Men binaries, it casts the ambiguous and rather counterproductive impact on the public opinion as regards the nature and the level of religious persecution. The politico-social consequences of this ambiguity can even be seen on the Sufi nationalists as well as on the Dalits impressed by the narrative offered 
by Amar Jaleel or other Progressives, when they allege 'forced conversion' ${ }^{10}$ of Hindu and Dalit. Despite the fact that most of such marriages and conversions are consensual, Dalit and Hindu girls are depicted as Marvis of Sindh under the bondage of Umar, a mythologized king of the yore who had kidnapped Marvi, a Hindu Dalit girl ${ }^{11}$. These kinds of stories inspired by idealized folkloric narratives of force, coercion and seduction and rape, are uncritically grafted upon such occurrences of Dalit women's elopements to hide their patriarchal bias. Seduction, rape, consensual sex, minor or adult age marriage of Dalit and Hindu women with the Muslim men are thus reduced to a single libelous denominator of 'forced conversion', the religious connotation that is in line with Sufi nationalist ideology (as well as in line with Political Islam of the state and Hindutva ideology) that suggests to imagine in terms of religious binaries.

${ }^{10}$ The cry against Forced Conversions in Pakistan raised by the Savarna-Ashrafia Sindhi nationalists and the Christian elite in July 2019 made to the Congress of the United States. See: The Pioneer (July 21, 201910 US Congressmen ask Trump to raise issue of Sindh with Pak PM

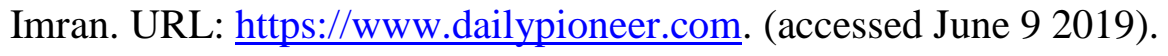

See also India Today (July 22, 2019) URL: https://www.indiatoday.in. (accessed June 9 2019).

${ }^{11}$ The reinvigorated literary assertion of Sindhi nationalists during the 1050s that reframed the narrative of Marvi was also noticed by Levesque and Camille Bui (2014) in their cinematographic study of first Sindhi movie 'Umar-Marvi' made in 1956. They argued that the movie 'contributed to the construction of a modern national imaginary for Sindhis in postPartition Pakistan' (see Levesque et al, p.119-121). 


\section{Infidel and the Progressive Solution to Ashrafia-Savarna domination}

Like any other piece of literature, one of the social utility of the short stories is to explain the social and political phenomena. 'Kafir' (infidel), a short story written in 1960s by Naseem Kharal, the Ashrafia class feudal, furnishes one of the exceptionally counterintuitive anti-caste narratives. The patriarchal import of the 'Infidel' is ignored, and often presented by the Progressives as the explanation of both the religious and caste discrimination and untouchability that pervades across religions in Sindhi society, and to prove that Sufi nationalist path is the most appropriate one for the (Hindu) Dalits to mutually coexist in the predominantly Muslim Sindh. Before, further elaborating upon it, I quote from the story a dialogue between a supposedly Hindu Dalit convert to Islam and a Mukhi (a community head):

Mukhi, the panchayat headman of Oad [Dalit] community begged in the name of holy

Gita and even threw his turban at Seetal's feet, but Seetal just didn't care much and replied:

"Mukhi! Do whatever you like, but I shall change my religion.

Mukhi: "But why after all you do, you want to change your religion?

Seetal: My choice, my wish simply.

Mukhi: Even then?

Seetal: I just don't like my religion. That's it.

Mukhi: Alas! Why on earth don't you like your religion?

Seetal: Alright Mukhi. Tell me who are we?

Mukhi: We are Hindus.

Seetal: Why then Hindus cremate the dead, whereas we bury them?

Mukhi: It's our ritual. 
Seetal: Alright, Why do we eat goat after butchering it (like Muslims)?

Mukhi: This too is our ritual—since the times of old ancestors.

Seetal: But these are the rituals of Muslims!!

Mukhi: These are theirs. But ours too!!

Seetal: Then how can you say, we are Hindus?

Mukhi: Then what the heck are we, crank?

Seetal: Half-Half Hindus, half Muslim. Body of sheep, head of goat." (Excerpt translated from Kafir, a short story by Naseem Kharal ${ }^{12}$ ) In this conversation, Seetal stands accused before the Oad (Dalit) community of betraying communal norms to convert to Islam, and proclaim that the Hindu religion is based on falsity. Although infuriated, members of the Oad panchyat (caste council) were not very harsh at Seetal, as they believed that Seetal had been bewitched by a Mullah (Islamic cleric). They tried to convince Seetal that he had made a blunder, but Seetal remained adamant that he was happy with his conversion. Having seen his resolve Mukhi made the final attempt to convince Seetal saying, 'Remember Seetal! No matter how lavishly you harness donkeys like horses, they will remain donkeys, and never become horses.' (i.e. no matter how good a Muslim you become, you will remain untouchable in their eyes). Seetal's adventure ultimately ends up with his realization that in case his ailing wife (who had also converted along with him) dies, he cannot be given woman for marriage from Ashrafia or Pasmanda Muslim castes, simply because he was considered as

\footnotetext{
${ }^{12}$ Source: 'Naseem Kharal Joon Kahariyoon' (2007), a compilation of short stories in Sindhi language by Danish Nawaz. Roshini Publications, Kandiaro. URL: www.sindhsalamat.com. This story was written in 60s by Naseem Kharal, the renowned upper caste landlord (wadero), and one of the leading Sindhi progressive writers of the 60s and 70s.
} 
'lower caste' or 'untouchable'. The realization of being 'untouchable Muslim', lower in status than the Pasmandas who had converted long before him. Ultimately, Seetal converts back to his former faith. The story, thus, ends with the bigoted disappointment of the Molvi (religious) at the re-conversion of Seetal, who says the 'Infidel is after all infidel'.

The story brings out very sharply that caste discrimination is a trans-religious phenomenon, and even stronger than religious affiliations. Rita Kothari (2009), a Savarana Sindhi Hindu, based in Ahmedabad in India has translated 'Infidel' from Sindhi into English Infidel (Kaafir), and has discussed primarily to show that such stories were the product of nostalgia of business class (Jati) Hindus and the post-Partition redemption of Sindhi Muslims who desired to reclaim their imagined syncretism between Sindhi Hindus and Sindhi Muslims that they wanted to believe existed in Sindh before Partition (see, Kothari, 2009) ${ }^{13}$. Hence, the exchange of persuasive dialogue in 'Infidel' is often interpreted by Sindhi nationalists and the progressive writers as the caution against the threat to an 'exemplary' interfaith harmony that once existed between (Jati) Hindus and Muslims

In this particular case, deviating from the Progressive's typical stance, Dr. Ghafoor Memon, however, argues that the major import of the story is to show that cultural and class (caste)-based norms are stronger than religion. He argues that Muslims are proved to be hypocrites as on the one hand they believe that there is no discrimination in Islam based on caste, on the other they also discriminates as do the Hindus (Memon, 2002. p.345). Rasool Bux Paleejo, a leading Marxist-nationalist also affirmed the factual relevance of the story:

\footnotetext{
${ }^{13}$ Rita Kothari (2009) has translated from Sindhi into English some 22 short stories mostly written by Sindhi nationalist writers, mostly (Jati) Hindus or Savarna Sindhis (living in India or in diaspora) and Ashrafia Muslim Progressives living Sindh.
} 
One the one hand we surpass all limits of exaggeration and slogan mongering to prove that there is not caste system in Islam and on the other, in reality, we are the leading custodians of the system of untouchability and casteism. Rasool Bux Paleejo in Memon, 2002, p.346)

The recognition of the problem of casteism, however, does not bar the Progressives to look for its antidote in Marxism and nationalism. The moral of the story that is often highlighted by the Progressives is related to 'interfaith harmony' or the religious discrimination instead of the embededness of patriarchy and caste under the gloss of religion. As Memon argues, this story supports the argument of the communists that social equality (devoid of casteism) can be achieved through socialism and communism, that ensures economic equality, and the values of equality so generated out of such a system will eventually eradicate casteism and untouchability (Memon, 2002, p.346). This traditional Marxist-nationalist approach to the problem of caste by the Progressives relegates casteism and untouchability to the second order issue supposed to vanish away once communism prevailed.

'Infidel' is used by Sufi nationalists or the Progressives as the explanation of caste discrimination by the Muslims against the Hindus(Dalits), to convince the Dalits that conversion cannot bear the requisite benefits. For instance, motivated by Taj Joyo (the Ashrafia Sindhi nationalist activist and the writer), who projected that story ${ }^{14}$ to prove that the recurrent abortive attempts at conversion to get rid of 'untouchability' and religious discrimination do not work.

\footnotetext{
${ }^{14}$ See online blog written by Sufi Ghulam Hussain (me) on December 9, 2017 titled Why Dalits in Pakistan are reluctant to convert to Islam en masse! URL: http://roundtableindia.co.in/. (accessed on March 19, 2019)
} 
Taj Joyo, for instance, wrote in Hemandas Chandani's (Scheduled Caste activist and poet) $\operatorname{book}^{15}$ :

I remember for sure that it was the night of December 11, 1977, when I met at Hemandas' home. I had a chit chat with Kanji Mal (officer national bank), Ganesh Balani, Bhani Mal, Sarvan Kumar, Naraern and Heman [all Dalits of Meghwar caste]. If I remember correctly, either Ganesh Mal (or any of the friends present) put up a proposal that 'we Meghwar are considered as lower-class Hindus, by caste Hindus. Therefore, our survival lies in converting to Islam'. There, I opposed that thinking that it is not the solution, because caste-based class discrimination also exists among Muslims. No Sayed Muslim will allow marry his daughter into any other caste, not to mention of Machi Muslim (fisherman caste considered the lower among Muslims). Although the days have much changed now, but even then, I narrated them the fiction story (based on social reality of casteism among Muslims) of Naseem Kharal. Finally, we came to a consensus that the solution of social discriminations lies in 'education and only education'. Today I feel proud that it is the effect of my ideas and the fiction story of Naseem Kharal narrated by me, that Ganesh Balani's four daughters have now reached the highest educational achievement: Shabnam Rathore made Sindh famous by doing PhD from Germany in 'Underground Saline Water'. Another Pushpa Kumari has done M.Sc. from Agricultural University Tando Jam. Third daughter Nimrita, is a lecturer in Sindh University's microbiology department.

15 The book by Heman Das Chandani titled Humerche Hoongar (Sindhi) was published in 2017. 
Fourth Sushhma Devi who did M.Sc from botany and serving as lecturer in Karachi".

(Taj Joyo, Preface to Hemanda Chandani's Humerche Hoongar, pg. 12)

As it is evident, Taj Joyo suggested the Dalits to get Sindhised without conversion as there was caste discrimination and untouchability even among Muslims. It was the suggestion more in line with the Sindhi nationalist ideology that desired unity between Hindus and Muslims instead of suggestive of the political way out of the caste discrimination and untouchability. The best of the solutions that Joyo proffered to these structural and political issues was the uplift through educational achievement at individual level. Following that logic, some of the Dalit activists whom Joyo met, tended to avoid conversions, or at least discourage it despite the fact that untouchability and caste discrimination continues to exist both among the Savarnas and the Ashrafia castes, and subsequently between the Dalit castes as well.

Like Joyo, the Progressives have convinced many Hindu Dalits not to convert and express their fidelity with the Muslim dominated Sindh through the Sufi nationalist medium. This suggestion, however, does not bar Dalits Ashrafise without conversion, that is, to revere Sayeds, Pirs and Sufis is adopted while remaining Hindus. Looking from the Ambedkarian perspective, this form of ritual inversion, however, does not resolve the fundamental problem, that is, caste discrimination and untouchability, and resultantly 'dissonance' (Festinger,1962; Hussain, 2019) persists between the assumption of being Sufi Sindhis and the empirically existing caste based discriminatory practices within Sufi nationalist domain (see Hussain, 2019b). Contrary to the Progressives' claims, the Ashrafia intervention into Dalit spaces of decision-making and identity (re)formation, proves the persistence of hegemonic influence of Ashrafia class over the (re)construction, (re)formation and the negotiation of Dalit identities, 
thereby disallowing them to come up with their own alternative counter-hegemonic narratives (see Guru, 2011a).

Consciousness of being sandwiched in between Brahminic and Ashrafia hegemons, some Dalits activists, particularly the Ambedkarites have turned into crypto-Buddhists. Politically they tend to follow B.R.Ambedkar and cherish Buddhist practices, but culturally go by the normatively sanctioned Hindu and Ashrafia practices. Generally, at the level of society, the mass conversions of Dalit families, particularly the poorest ones, continues unabated, and often go unnoticed (See Wajid, 2017; CIFORB, 2018) which proves that most of the conversions are not motivated both by the economic and social (untouchability) reasons to have a relatively better status instead of the ideally perfect one based on equal treatment as suggested by the short story 'Infidel'.

\section{'The Prisoner of Karoonjhar' and the Appropriation of Dalit Heroes and Spaces}

The inversion of the history of a Dalit rebel/ fighter is exemplified in 'The Prisoner of Karoonjhar $^{16}$ (Karoonjhar jo Qaidi), a short story written by Ali Baba (Rind Baloch by caste). In this story, Rooplo Kolhi is depicted as the hero of Sindh who fought bravely during the middle of the $19^{\text {th }}$ century when the British attempted to establish its writ over Parkar, a small mountainous region surrounded by Rann of Katch on the south and Thar Desert of Sindh on the North. Rooplo Kolhi, as the locals believe, was a Girasia, that is, the tribal chief recognized as such by rulers of the time, particularly by the Mughals (see Mal, 2000; Kolhi V., 2011; Kolhi B. M., 2014). The narrative depicted in Ali Baba's story is not much different than most of the Kolhis and Sindhi people believe in. It has both emancipatory as well as hegemonoic and counter-hegemonic aspects depending upon who patronises whom.

\footnotetext{
${ }^{16}$ Karoonjhar is an isolated mountain about 7 kilometers in length at the center of Parkar, the hiding place for the rebels during the British occupation of Tharparkar.
} 


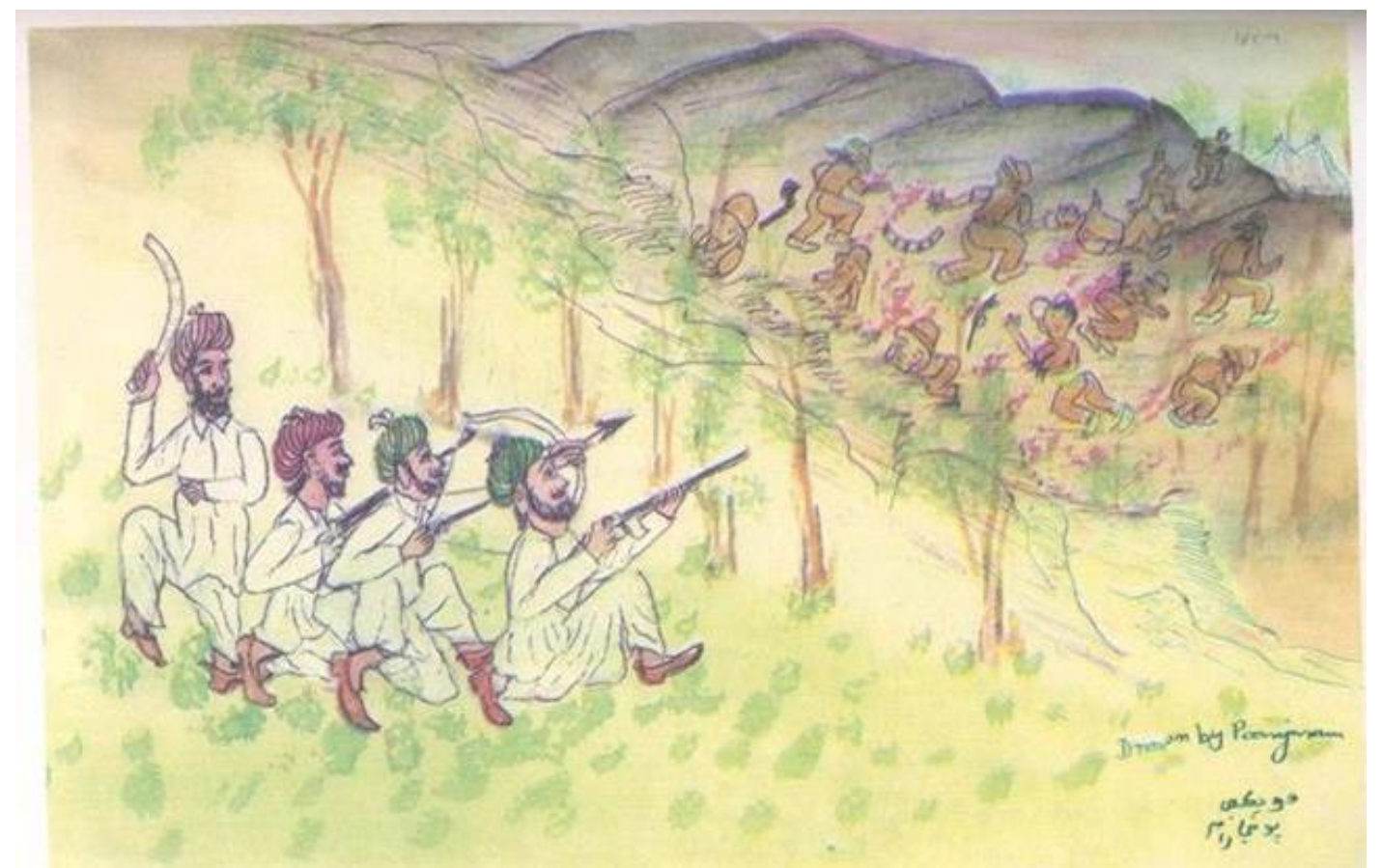

Figure 1: The painting popularized by Parkari Kolhis depicting Rooplo Kolhi along with his rebel friends attacking the British in Karoonjhar Mountains at Parkar, (Source: social media, shared by Dalit activists) ${ }^{17}$

Ali Baba's narrative of Rooplo Kolhi's bravery situates Rooplo as if in direct confrontation with the British, and it goes like this:

As if the British canons were roaring. [...] As if hearts of Samma, Soadha, Soomra,

Thakur, Rabari and Kolhi women were being ripped asunder. [...] Rano, Tkhakur,

Khoso, Rathore, Samon, Soomro, Parmar and Kohli all had sacrificed their lives for the sake of Karoonjhar (pg.14).

$[\ldots]$

[The battle was not over yet] the English would trigger the canons because Ranas [Sodha Thakur rulers of Parkar] has not given up yet. Thousands of Kolhi, Bheel, Rathore, Samma and Khosa were roaming secretly in the valleys of Karoonjhar Mountain (p.14-

\footnotetext{
${ }^{17}$ Nobody holds the copyright to the picture. It was painted and printed for a book on Parkari Kolhis written by Paru Mal Kolhi( see Mal, 2000). I have, however, sought the permission from the relatives of the author to re-use the picture for the research purposes.
} 


\section{$[\ldots]$}

No sooner did that night fall, Kolhis would began attacking the pickets of the British army.[...] The British did not confront such kind of rebellion in any other part of the Hindustan $[\ldots]$. When captain Tyrwhitt received an indictment from Sir Charles Napier, he simply sent a reply, 'I regret. Here we are not fighting with the people but with the terrifying volcanic mountain'. The poor captain Trywhitt felt himself at his wits ends. $\mathrm{He}$ was unable to devise any way to control Ranas (Sodha Thakurs) and Kolhis (p.g 15). $[\ldots]$

[Compares Rooplo Kolhi with Hindu Vedic Gods]

That Kolhi was tall and dark brown like the Shri Kirshan Mahrarj of Hindu sacred books, and as resolved and steadfast as Arjun Maharaj (p. 15)

[The British new that whom they were fighting with]

'Roopa [Rooplo Kolhi] we do not want to kill you. You just simply tell us the whereabouts of Ladhoo Singh and his accomplices. We will confer upon you the fief as per your desire'.

[The writer begings projecting Rooplo as the self-motivated fighter who damn cares about Ladhoo Singh]

'This whole land is mine. Who the hell are you to give that back as a fief to me?'

'Were you not a slave of Rana Ladhoo Singh?'

'No, I would have shoot Ladhoo Singh, if I had felt that I were a slave of him' (p.19).

[Rooplo's wife is depicted as steeped in patriotism]

'Roopa, I have come to see you the last time. Never ever make me the object of ridicule before Kolhi women. Never give up. Otherwise, I shall abandon you. Moving her hand 
over the pregnant belly I shall proclaim that this child is not begotten of Rooplo, but of someone else' (p.17)

[Writer dilutes caste disparities by showing that Meghwars were anti-national and assisted the British]

'They were Ladhoo Singh and Rooplo, from whom you had escaped and had been given refuge by hiding under the skins of Meghwars' [p.18]

[Ends the story by showing the colonialist minds as psychologically disappointed after Rooplo's resistance]

For the first time, Trywhitt felt that no alien nation can occupy the lands of foreign nation for more than 25 years, but they might be compelled to vacate Karoonjhar probably even before 12 years.

As it is evident from the above excerpts of the story, Rooplo Kolhi is depicted as the independent freedom fighter who fought against the British to reclaim his 'Mulk' (Parkar). The impression is created that Parkar was a part of Sindh and Rooplo, therefore, fought for Sindh. Karoonjhar symbolizes Sindh in miniature and the local castes symbolized the Sindhi nation that was resisting against the British. In a latest 'progressive' compilation of essays in Sindhi, Rooplo Kolhi's confrontation with the British is projected not just as fidelity to the local 'upper caste' rulers but to nation. For instance, equating tribal ethic to stand by the side of the local ruler with the national patriotism, Dr. Azad writes:

By having a look on the overall scenario during that period, it becomes evident that it was the period during which to remain loyal to the local ruler under the given tribal system was considered as loyalty to the nation. By and large the same kind of struggles can be evidenced during Mughal era against British. (Qazi, 2015, p.11) 
This nationalist projection, that legitimizes the subordination of the oppressed castes to the local oppressor castes for the sake of freedom from or resistance to the external forces (the British), undermines the agency of the Dalits both in the historical past as well as in the present by suggesting Dalits to play second fiddle as loyal subordinates to the Ashrafia-Savarna castes. In contemporary Sindh, where these caste-based or the tribal relations of domination and subordination still exist with some minor variations though, this nationalist logic that has reidentified Pakistani establishment or Punjabi domination as the new 'other, in a way, allows the subordination of Kolhis or Dalits to Sodha Thakurs, Khosas, Mir Talpurs and even to Sayeds. Hence, this tribal-nationalist ethic even applies today, and may continue to be applied by the Ashrafia-Savarna castes in the name of the external threats to the internal tribal-caste (dis)harmony.

Prior to that appropriation of Rooplo Kolhi by the Sindhi nationalists, it was almost vice versa. The review of the vernacular literature written by Parkari Kolhis , and the conversations held by me with the local Parkaris in 2019 indicate that Parkaris did not always imagine Parkar as the part of Sindh. A Tharparkar based Dalit activist inverted the nationalist narrative in the following manner:

Mado Meghwar, who gave refuge to Trawat $\left[\right.$ Tyrwhitt $\left.^{18}\right]$. Do you know why he gave refuge to tarawat? Very few know. You must see, during that period, the poor classes...in 1800s.the first Dalit woman who wrote a letter...she only was class VIII pass. She was ... Savatri Bai phule....she writes that they were the English people who came in and freed us from clutches of the upper castes. They see the coming of the British as the precursor of emancipation. They supported the British. Similarly during the 1857 war, the

\footnotetext{
${ }^{18}$ Trywhitt was a British appointed captain and administrator at Parkar and was assigned the task to subdue Sodha Thakurs.
} 
Sikhs allied with the British to get rid of Mughal persecution. Similarly, Meghwar like Madhu, and the people of Parkar, particularly Dalits, sided with the British as the emancipators who got them rid of the domination of Sodha Thakurs. And this [Rooplo], who was the paid mercenary of Sodha Thakurs, is now reckoned as the hero in history. But those like Madhoo Meghwar who supported the British to get rid of Sodhas persecutors are condemned as the rebels.

Like Dalits themselves, this counter narrative is also very marginal and very few even among Dalit activists subscribe to an essentially Ambedkarian perspective on history and historiography. Yet there are many points on which they converge and that deviate from the Ashrafia-dominated nationalist narrative.

Before the Partition of the subcontinent, Parkar was imagined by Kolhis as well as by other Parkari communities as 'Mulk' (literally, a country different from Sindh) (Mal, 2000; Kolhi V., 2011; Kolhi B. M., 2014). 


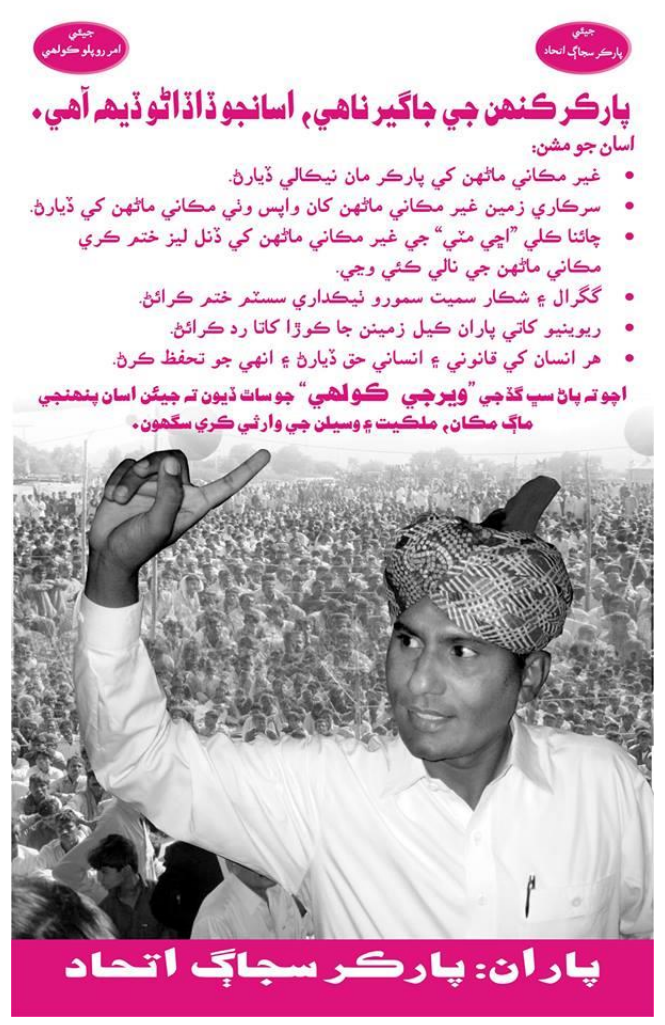

Figure 2: Local Government elections (2013) pamphlet of Veerji Kolhi reads: Parkar is not the private property of anybody, but our fatherland. Source: Author (2016)

Given the historical profile of the characters, which is very vague though, this story by Ali Baba cannot be interpreted like the other two discussed above that are essentially based on fictitious characters. In this story history is inflated through fiction; while in the previous stories, fiction is created to depict contemporary social reality. Hence, the characterization of Rooplo Kohi through Ashrafia literary narrative has the historically real import for Kolhis, Dalits and the Progressives alike. It has contemporary political relevance as it seems in line with the Dalit's tendency to ashrafise (see Hussain, 2019b; Mal, 200) by labeling Rooplo as 'shaheed' (ArabicSindhi term for the martyr), and by tracing the existing descendants of him. Off and on,

${ }^{19}$ This is the pamphlet widely disseminated for public use for political purposes. 
individual Kolhis claim to be Rooplo's grand-grandsons ${ }^{20}$ and are invited in annual anniversaries organized to pay homage to Rooplo as guest speakers. This desire to associate with Rooplo is the post-1970s phenomena, resonates with the Sindhi nationalist narrative as it was projected through political speeches and the politico-literary writings as that of Ali Baba.

The narrative of the story, however, loses its historical grounding and the authenticity as there is not much historical evidence to support the facts related to Rooplo or Kolhi community's role in the fight against the British. The historical chronicles, mostly written by the British officers, do not mention about any such dramatic debacle involving Rooplo Kolhi (see for instance, Raikes, ((1856) 2009). Although the narrative apprently looks emancipatory for Dalits as it highlights Rooplo Kolhi and undermines the role of Sodha Thakurs, yet it loses ground when assessed based on historical facts that lack in many ways.

Ali Baba's narrative undermines the fact that Rooplo fought as a tribal chief of Kolhi's Gohel sub-caste under the supervision of Ladhoo Singh, a Kshatriya or upper caste Hind ruler (see Raikes, ((1856) 2009). Parkar had been under the control of SodhaThakurs during the past several

${ }^{20}$ During the conversational interviews, Dalit activists told that Satram Das of Atran Mori claimed that Rooplo is his grandfather. Comrade Bhagat Padhmon Kolhi of Sindhin jo wandyo filed a case to get 50 acres of land of Parkar based on his claim that he was grandson of Rooplo. Veerji Kolhi (advisor to minister) and Krishna Kolhi (senator) claimed to have descended from Rooplo Kolhi. Lately, a team of local progressive-minded researchers led by Mir Hasan Arisar, Tahir Mari, Nawaz Kumbhar, Muhib Bheel, Sadam Dars and Ranshal Das attempted to locate the true ancestors of Rooplo Kolhi. According to their findings, Rooplo had a son called 'Harkho', and that Kheto Mal and Gulab Rai were the true grand-grandsons of 'Shaheed Rooplo'. 
centuries. Talpur and Kalhora rulers of Sindh occasionally used to intervene in Tharparkar to establish their writ, which was often thwarted by the Sodhas. Sodhas of Parkar had their own communal system of management that they used to call 'Gurr Raj', and variant of land tax collection called 'Raney jo Jalang'(sack of Rana) was in vogue by virtue of which all Rajputs /Sodha Thakurs were exempt from the land tax (Qazi, 2015, p.7-8). While Parkar had its own semi-autonomous political economy, it was not completely independent of the influences of the rulers of Sindh and were given various exemptions and waivers to collect taxes from the local pastoralists and peasants. (see Ojha 1966, p.104). When the British conquered Sindh in 1847, they reduced the Rana's right and share of taxes to a half, while allowed them to maintain their own jagreers (fiefs) ( Qazi, 2015, p.7-8)

Similarly, both the Ali Baba as well as Parkari Kolhis do not bring into framework the fact that Meghwar community (Dalits) had already submitted to the British to emancipate from the Sodha Thakurs. They also undermine the fact that Talpur rulers of Sindh were also subdued by the British and even employed against the Sodha Thakurs (Mal, 2000; Kolhi V., 2011; Kolhi B. M., 2014). They also neglect the fact that it was the army of Talpur rulers of Sindh that fought together with the British to crush Sodha Thakur resistance in Nangarparkar (see Raikes, ((1856) 2009). They do not acknowledge that Parakari Kolhis, in fact, fought as army men for the Sodha Thakur (Savarna) rulers of Parkar, who did not even consider Kolhis as proper Hindus.

The historically anomalous ethnic and geographical status of Parkar can also be confirmed from the fact that before the annexation of Parkar to Sindh by the British, Parkar was under the jurisdiction of Bhuj (Katch, now in India), and that both the Dalits and the Savarnas of Parakar were ethnically and politically aligned more with their respective caste fellows and co-religionists in Kutch than with the land and people of Sindh the borders of which 
lied where from the Thar Desert began ( see Mal, 2000; Kolhi V., 2011; Raikes, ((1856) 2009); Kolhi B. M., 2014). Similarly, the local narrative about the British agent Tyrwhitt, who is now demonized as the persecutor, was hailed as local hero by Tharparkari people. Abdul Qadir Junejo writes:

Thari people have unique instinct of liking and making heroes for themselves. Mughal Emperor Akbar was a legendary figure for them only second to local deities, so was General Taroot (Tyrwhitt). Despite the fact that Taroot was the one who overwhelmed Sodha Rajputs and hanged Rooplo Kolhi, he was highly praised and eulogized by Tharis in folk songs, and folklore during and after Taroot's times. (Junejo, 2010, p. 126)

This pre-colonial narrative was gradually overtaken bythe postcolonial nationalist narrative whereby the praise of Tyrwhitt was considered as symbolic of the slavish imperialistic attitude. Given this ambiguous history, it can be argued that the Progressive's narrative of Rooplo Kolhi, that is inadvertently, picked up by Dalits as well, is premised on the self-serving all-unifying nationalist fantasy that more than giving the emancipatory push to the Dalit cause rather hampers it. Kolhi activists, consider this projection as the sort of recognition of the value and worth of Kolhi community within the comity of Sindhi castes, and see this re-nationalization of 'Amar (eternal) or 'Shahee' (Martyr) Rooplo Kolhi', as the derive to create social and political space for their marginal community (Mal, 2000; Kolhi V., 2011; Kolhi B. M., 2014). Hence, except the minor antipathy towards Ashrafia-dominated Sindh that sometimes reflects from Kolhi's hidden script, Parkar is largely imagined by them as the integral part of Sindh, and Rooplo as the foremost Sindhi national hero, the recognition that could not be had without the approval of 'authentic nationalists' (i.e. Ashrafia-Savarna elite). 

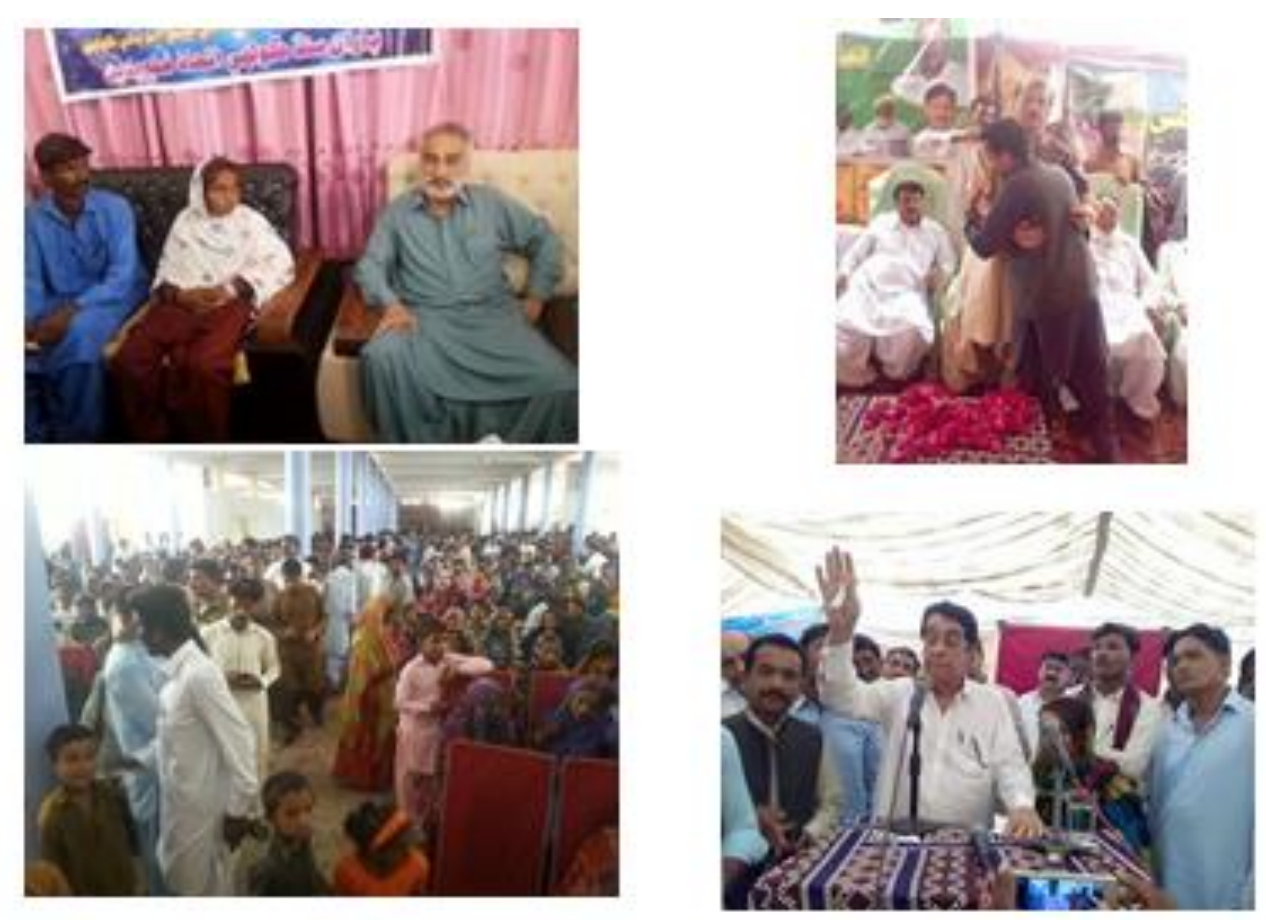

Figure 3: Snaps from two different programs organized by Kolhi activists to celebrate death anniversary of Rooplo Kolhi. The chief guests invited belonged to the ruling Talpur and Mirza Ashrafia castes. Source: Author (2016) ${ }^{21}$

To reciprocate that recognition and to reaffirm their fragile bonding with the Ashrafia class,

Kolhis invite Mirs, Sardars and Sayeds as special guests in their programs held to commemorate the martyrdom of Rooplo. Affirmations and the egalitarian rhetoric, for instance, follow from the mouth of Ashrafia elite in the following manner.

'To be Kolhi is the matter of pride. Civilization cannot be erected by becoming Sayed.' (Sardar Shah)

'I will try to convince my party leadership to ensure representation of Kolhi community in the parliament. 22 (Sardar Shah)

\footnotetext{
${ }^{21}$ The pictures were taken by a Dalit activist.

${ }^{22}$ Source: Daily Ibrat (Sindhi newspaper, Dated, $28^{\text {th }}$ August, 2017. URL: http://www.dailyibrat.com/beta/pages/jpp_28082017015347.jpg
} 
'Rooplo Kolhi fought the battle against the British forces for the Sindh, and sacrificed his life. The youth should follow the example'. Nawab Yousaf Talpur

'We are proud of Rooplo Kolhi. He fought the war for the survival of Sindh'. Nawab Taimur Talpur (MPA) $)^{23}$

'Rooplo Kolhi memorials will be built in each major city including Karachi' (Ibrat daily, Sindhi newspaper).

'The Dravidians and politicians of Sindh declared immortal Rooplo Kolhi, the son of the soil. ${ }^{24}$

This ritual of ritual of inversion at the behest of Ashrafia elite, under the influence of Sufi nationalist narrative, dilutes the question of casteism such that Rooplo Kolhi (a Dalit), Hoshoo Sheedi (an Afro-Sindhi descendant of slaves), Dodo Soomro (Sammat ruling caste elite) and Raja Dahar $\left(7^{\text {th }} \text { century Brahmin king of Sindh }\right)^{25}$ are projected as standing on the horizontal socioeconomic plane that demands of them to struggle for Sindh. It creates the false dichotomy between the two groups of Ashrafia-Savarna classes, namely the Sindhi nationalists and separatists, and the pro-state feudal Sindhi Ashrafia class. For instance, a Kolhi activist aligning

\footnotetext{
${ }^{23}$ Source: Sindh Express (daily), Monday, August, 28, 2017. URL: http://sindhexpress.com.pk/epaper/PoPupwindow.aspx?newsID=130546486\&Issue=NP HYD\&Date=20170828 ${ }^{24}$ Source: Daily Sobh (Sindhi newspaper), Dated, $28^{\text {th }}$ August, 2017. URL: http://www.dailysobh.com/beta/epaper/news/news.php?news_id=236.

${ }^{25}$ Some historiographers depict Dahar as an unpopular Brahmin king that ruled over Buddhist majority, and Chach, Dahar's father is believed to be the usurper of Buddhist Rai Dynasty (see
} Nicolas, 2006; Naik, 2010, p. 32.) 
himself with the nationalists as against the ruling feudal class of Sindh uploaded a Facebook status:

The $159^{\text {th }}$ anniversary of Shaheed Rooplo Kolhi was celebrated by Jeay Sindh Mahaz at Sachal village, Karachi. Chairman of Mahaz, Abdul Khaliq Junejo said that Raja Dahar, Hoshoo Sheedi and Rooplo Kolhi are our valiant heroes, and that Muhammad-bin-Qasim is historically condemned as the imperialist. He said that the anniversaries of Rooplo are being celebrated lately by the ruling elites since the last two-three years to appropriate Rooplo for their vested interests. But they must remember that the resistance of Rooplo was not simply for capturing seat in legislative assembly or to appease any specific sect, but for his land Sindh, the legacy of which rule-hungry elite cannot be the inheritors.

(Ranshal Kolhi, Facebook Status, 24 ${ }^{\text {th }}$ August, 2019)

These acts of counter-appropriation, condensation and equalizing Savarna-Ashrafia and Dalit heroes in the name of resistance against the non-nationalist ruling elite are not liked by some of their co-Dalit activists, best classified as Ambedkarites. For instance, an Ambedkarite interviewed by me lamented:

It's not just that simple, that democracy fascinates Dalits. Under it, they eagerly sell out their heroes to nationalists, and give away their gods to Brahmins and Lohanas; they are willing to banish all their ancestral gods to exclusively worship Ram, Krishana and Ganesha.

(Dalit activist [anonymized], Personal Interview, 2016) The unabated influence of Sindhi Progressive narrative had been lately (between 2016 and 2019) disturbed by the group of activists affiliated with Dalit Sujaag Tehreek, who were working 
within several other splinter groups. The change was noticed during the $160^{\text {th }}$ anniversary celebrations held at Judho and Hyderabad by Sindhi Kolhi Itehad and Pakistan Kolhi Itehad in which they consciously took the decision not to invite, as chief guests, the feudal or political class person elite. Yet this not yet institutionalized and abrupt change is not without ideological problem as the majority of Dalits continued to imagine Rooplo and Dalits through Marxistnationalist lens instead of Ambedkarian one. Pahlaj Kolhi, the organizer of anniversary at Jhudo post on Facebook a happy note:

This was apolitical anniversary. In this anniversary there was no minister, advisor or senator. Despite that the sea of people flooed in, which proves that people have now do not accept this waderko-bhotarko (feudal) system.

This apolitically framed political statement about the program in which they awarded Dalit activists affiliated with different political parties for raising voice for indigenous 'Darawar' communities, framed the issue in a Marxist language of class struggle that obfuscates the problem of casteism. Hence this Dalit agency that is carried away by the Marxist-Ashrafia ideology, many Kolhi activists see this re-nationalization of 'Amar Rooplo Kolhi' as the drive to create social and political space for their marginal community (Mal, 2000; Kolhi V., 2011; Kolhi B. M., 2014). Given this ideologically confused nature of Dalit activism, many of them are not much optimistic that the social hierarchies would alter in any fundamental ways.

Looking from the Ambedkarian perspective, this anti-colonial narrative could have been truly emancipatory, if it had also brought into focus the internal colonialism based on exclusion of Dalitbahujans. Since, it was not the case, and the Sufi nationalist projections of the Progressives undermined caste (also gender) as the political factors of oppression and exclusion, the postcolonial emancipation from the British imperialism cannot be understood by the 
Ambedkarites as the Dalit emancipation from the internal colonialism. Hence, the story of Rooplo Kolhi, as it is depicted and projected seems quite the reverse of Ambedkarian way of hero-making. For instance it is quite the opposite of the battle of Koregaon in which about 500 Mahar (Meghwar) of Bombay Native Infantry of the East India Company fought against the Peshwa rulers. The event is considered as the revenge of decades of treatment of Mahars as untouchables, and which is projected as the source of revolutionary inspiration by the Ambedkarites. Millions of Dalits gather each year on the $1^{\text {st }}$ ofJanuary in Bhima-Koregaon village in Pune, India to celebrate the event (Zelliot, 2011; Kumhoikar, 2012). ${ }^{26}$

To sum up, the symbiosis of the Dalit and Ashrafia Progressive narrative seems counterproductive for the Dalit's own emancipation, as it merely dilutes the question of existing caste discrimination and appropriates Dalit history without proffering them emancipation, reciprocal respect, inclusion or the social justice. By showing that Rooplo stood for Parkar, the geographical region which is now projected as the integral part of Sindh, the Progressives suggest to stand for Sindh against the external enemy that may be the British or the PunjabiPakistani establishment. Many Dalit activists, mostly Parkari Kolhis, however, do not buy the Progressive's narrative wholeheartedly, and do not consider Pakistani establishment as their enemy. Moreover, they could not have forgotten the persecution that they suffered at the hands of the local Ashrafia and Savarna elites of Parkar. For instance, Mavo Kolhi, in the anniversary of Rooplo Kolhi lamented the fact that:

26, The Battle of Bhima Koregaon Documentary Film Official Release | Director - Somnath Waghamare, Published by Roundtable India on Aug 20, 2017, Direction and Camera - Somnath Waghmare ,Editor -Deepu ( Pradeep K P), URL:

https://www.youtube.com/watch?v=PDw43hJf_IY\&feature=share). 
A decade after Rooplo's martyrdom, in 1964 when the British was still there in Parkar, the incident happened in Holi Garho in Pithapur where Thakurs of Dedhvero, and Khosas of $\mathrm{Kabri}^{27}$ attacked the Chatro Kolhi and his son (would-be groom).

Thereafter, many Kolhis decided to leave Parkar migrate to Barrage area of Sindh to settle there permanently instead of returning back seasonally ${ }^{28}$.

The Progressives reconstruction of history could have been truly emancipatory for the Dalits if they had also brought into consideration these narratives of the Parkari that implicate the local Ashrafia and Savarna elite; or, for instance, Rooplo along with his community of Dalits had been depicted as fighting against the British or 'Company' with the consciousness of the fact that the Dalits were internally colonized and humiliated by the Sodha Thakurs and Ashrafia castes. Sindhi short story writers, being under the influence of Ashrafia Sufi nationalist narrative could not have gone to that extent to frame their narratives against their own political and literary class.

\section{Conclusion}

The analysis of the discourse emergent of the three popular Sindhi short stories in everyday politics in Sindh revealed that Progressive narratives do not sufficiently grasp the Dalit lifeworld and rather ignore them. The occasional appearances of Dalit men and women in Progressive short stories and in Sindhi civil society rather prove the periherality of Dalits in, Ashrafia-dominated literary and political spaces. Colored in Sufi nationalist ideology, the

${ }^{27}$ Holi Garho is small village in Pithapur which is union council of Nangarparkar. Dedhvero and Kabri are also villages of Nangarparkar that were dominated by the Thakur (Savarna) and Khosa (Baloh Ashrafia) caste groups.

\footnotetext{
${ }^{28}$ Transhumance has been a common migratory practice among Parkaris, who used to migrate from Parkar to the plains of Indus (locally known as 'barrage area'). Before Partition of the Sub-continent and the sealing of borders, they used to migrate to Kutch and Malwa in Maharshtra (see Mal, 2000).
} 
Progressives' definition of 'Dalit's oppression does not help invoke Dalit agency to emancipate from Sayedism or Ashrafia domination. Resultantly, the Ashrafia reader and the activist, instead of feeling remorse or shame on his or her casteist patriarchy, is led to objectify Dalit (women's) body, labour, vulnerability and haplessness.

The Progressives appropriate for their own vested interests, the spaces, events and Dalit's characters having potential of subverting Ashrafia-Savarna hegemony. I is evident that while the 'Progressives' in their writings and the ruling Ashrafia elite in their political acts apparently assume a critical posture towards religious suppression, casteism and or Sayedism, they are largely apologetic in their tenor, and do not show any commitment to the annihilation of casteism and inclusion of Dalits into privileged spaces of politics, society and culture.

Given the epistemological disparity between the huge volumes of the Progressive literature that ignores casteism, and the politically significant demographic strength, this Ashrafia (Savarna) intervention into Dalit spaces seems highly problematic. Amar Jaleel, Naseem Kharal and Ali Baba or even Noorul Huda Shah's ${ }^{29}$ depiction of Dalits and women, as it is inspired by their Gandhi-influenced Progressive predecessors, is comparable to the Hindi short stories of Munshi Premchand ${ }^{30}$ who have given space to Dalit characters and brings forth Dalit's exploitation in his stories, but his antidote was inspired by the functionalist approach of Arya

\footnotetext{
${ }^{29}$ To have an idea of Noorul Huda Shah's literary-political approach read her statements related to the literary production during General Zia's regime, the period during which she wrote several drama serials for state-sponsored TV channel PTV. Further read in DAWN, URL: https://images.dawn.com/news/1178036. (accessed June 7, 2019).

${ }^{30}$ To read online Premchand'some notable short stories, see : URL: https://www.rekhta.org/stories/eidgah-premchand-stories?lang=ur. (accessed June 6, 2019).
} 
Samaj, Dayanand Saraswathi and Gandhi, and supported the idea of purity (shuddhi) and was against religious conversion (Rabbani, 2016; Trivedi, 2017). Their narratives are unlike of Ambedkar's Dalit, who is courageous and infused with zeal to fight against untouchability and exploitation and live with dignity.

To evade this sociological reality, the Progressives give forth the post-hoc interpretations of the historical narratives, such as in case of Rooplo Kolhi, or appropriated Dalit oppression for their Sufi nationalist cause that diluted the problemtisation of casteism (also of gender discrimination) and highlighted the problem of religious persecution, fanaticism and also feudalism. The narrative of Rooplo Kolhi has both emancipatory as well as hegemonoic and counterhegemonic aspects depending upon who patronises whom. Since Rooplo did not primarily fought against Savarna-Ashrafia domination, and instead fought for restoring the Ashrafia-Savarna hegmony against the Britith (colonial ) domination, he cannot be invoked as a Dalit hero in an essntially Ambedkarian sense. Its dominant nationalist projection creates false pride in Rooplo and rather undermines the agency of the Dalits both in the historical past as well as in the present. By suggesting Dalits to play second fiddle as loyal subordinates to the Ashrafia-Savarna castes, the Rooplo's narrative in a way, dilutes the relations of domination and subordination existing between the ruling AshrafiaSavarna and the ruled Dalit castes.

The stories, in general, analysed the problem of casteism as peripheral to their projection of nationalist goal, to which caste is not a bigger hindrance as much as religion. Resultantly, instead of giving Dalits emancipating thrust, the stories end up abruptly leading the Ashrafia reader (for whose consumption they primarily write) to pity the Dalits and sympathize with them, while leaving Dalits in a state of self-pity. An Ambedkarite might have taken these stories further and have inverted the individual Dalits' tension into the collective resistance at the level 
of community. Hence, the Ambedkarites may make the counterintuitive demands from the Progressives to invert both the pure fiction and the fictionalized history so that the frictions of caste and gender, or the embededness of caste, gender and religion could be brought to the fore. Most of the Progressives seem incapable to fulfill that demand as it conflicts with their Sufi nationalist narrative.

Related to this epistemological demand, is the lack of privileged space afforded to Dalit writers to express their feelings and emotions that no Ashrafia writer can. Except ah few, which lie at the margin, there is not noteworthy Dalit short story writers found among the comity of the Progressives in Sindh. This situation, at least at the level of epistemic justice or equality, continues to be heavily tilted in favor of the Progressive Ashrafia writers whose primary aim, even while giving voice to the Dalits, has been to suggest the unity of all Sindhi castes including Dalit castes against the external Ashrafia oppressor.

The essential nature of the literature produced in Sindhi language gives voice to the Ashrafia-Savarna emotions and cherishes Ashrafia value systems that are fundamentally premised on the superiority of Sayeds, Sammats, Baloch and Savaran (Lohana, Bharamin, Thakur) castes. The Dalit middle class finding herself incapable to cope up with the highly elaborate Progressive narrative, either takes sides with the Sufi nationalists (Sindhi separatists, Marxists, pro-Pakistanis) of one type or the other, all of whom are invariably pro-Ashrafia in their social and political orientation and indifferent to the plight of Dalits.

Since the quantity, quality, content and the interpretation of short stories of the Progressives reflected above summarised facts, I conclude that although the narrative emergent of these stories creates a temporary anxiety in Ashrafia consciousness to confront casteism, yet it facilitates the appropriation of Dalit heroes and Dalit spaces by the Ashrafia elite and merely 
invoke token sympathy and compassion for the Dalit (women). Hence, the Progressives' social imaginary defies the Ambedkarian approach to society and politics that argues for the annihilation or eradication of casteism through concrete measures and conscious engagement.

\section{References}

Abro, Jamal (2015). Pishu Pasha aen Biyon Kahariyon.Roshni Publications Kandiaro Junejo, A.J (2004), “Sindhi Adab Ji Mukhtasir Tareekh" ( ${ }^{\text {st }}$ Ed), Sindhi Language Authority. Ahmad, I. (2003). A Different Jihad: Dalit Muslims' Challenge to Ashraf Hegemony. Economic and Political Weekly, 4886-4891.

Ambedkar, B. (1944). Annihilation of Caste with a Reply to Mahatma Gandhi (3rd ed.).

Ambedkar, B. R. (1947). States and Minorities (Memorandum on the Safeguards for Scheduled Castes). Bombay: Governmentt of India.

Ambedkar, B. R. (2014 (1991)). Dr. Babasaheb B. Ambedkar, Writings and Speeches, Vol:1-9

(V. Moon, Ed.) New Delhi: Dr. Ambedkar Foundation,Ministry of Social Justice \&

Empowerment, Govt. of India. Retrieved from http://www.mea.gov.in.

Qazi, Dr.Azad ( 2015) Shaheed Rooplo Kolhi, Roshni Publications Kandiaro

Behdad, A. \& Thomas, D. (2011). A companion to comparative literature. UK: Wiley Blackwell.

Buehler, Arthure F. (2012). "Trends of ashrafization in India." In Sayyids and Sharifs in Muslim Societies: The Living Links to the Prophet, by Morimoto Kazuo, 231-246. Routledge. Chandio, J (2016) Sandi Jogiyan Zaat. Peacock Publishers, Karachi.

CIFORB (2018). Forced Conversions \& Forced Marriages in Sindh, Pakistan, The University of Birmingham, UK. 
Damrosch, D. (2009). How to read world literature. UK: Wiley-Blackwell Publishing.

Sisir Kumar Das (2005)History of Indian Literature: 1911-1956, struggle for freedom :

triumph and tragedy. Sahitya Akademi.

Hussain. Dr. Fahmida (1997) “Adabi Tanqeed, Fann aen Tareekh”. Sindh Adabi Academy, Karachi.

Jaleel , A. (2010) Lahandar Sijj Ji Laam. Katcho Publication.

Jaleel , A. (1998) Dil Ji Dunya.Roshni Publications. Kandiaro

Jaleel, A. (2007) Ranni Kot jo Khazano. New Fields.

Jaleel, A. (2012) Jeejal Munhji Mau. Kacrho Publications.

Junejo, Dr.Faiz (2015) “Tabqati Fikir Ja Sindhi Adab Tey Asar” [Sindhi]. Sindh Sudhar

Publishers, Sindh.

Eagleton, T. (2002). Marxism and Literary Criticism. London: Routledge.

Gramsci, Antonio (1971) Selections from the Prison Notebooks of Antonio Gramsci, New York, International Publishers.

Guru, G. (1995, October 14-21). Dalit women talk differently. Economic and Political Weekly, 30(41), 2548-2550. Retrieved Accessed: 28-10-2017 20:35 UTC, from Stable URL: http://www.jstor.org/stable/4403327.

Guru, G., \& Sarukai, S. (2012). The Cracked Mirror: An Indian Debate on Experience and Theory. New Delhi, India: Oxford University Press.

Guru, Gopal. (2011a). "Liberal Democracy in India and the Dalit Critique." Social Research: An International Quarterly 78 (1): 99-122. doi:10.1353/sor.2011.0047.

Guru, Gopal. (2011b). "The Idea of India: 'Derivative, Desi and Beyond'." Economic and Political Weekly 46 (37): 36-42. URL: http://www.jstor.org/stable/23047279. 
Guru, G. (1995, October 14-21). Dalit women talk differently. Economic and Political Weekly, 30(41), 2548-2550. Retrieved Accessed: 28-10-2017 20:35 UTC, from Stable URL: http://www.jstor.org/stable/4403327.

Kumar, V., (2018) Locating Dalit Perspective of Social Reality, International Journal of Indigenous and Marginal Affairs, January-June 2018, 4(1), pp.57-78.

Lata, P. (2015, May 8). Silenced by Manu and ‘Mainstream’ Feminism: Dalit-Bahujan Women and their History. Roundtable India. Retrieved October 4, 2017, from https://roundtableindia.co.in/index.php?option=com_content\&view=article\&id=8177\%3 Asilenced-by-manu-and-mainstream-feminism-dalit-bahujan-women-and-theirhistory \& catid=120\&Itemid $=133$

Hussain, G. (2018, January-June). Legitimacies of Caste Positions in Pakistan: Resolving 'upper caste' delimma in shared space of knowledge production and emancipation. Panjab University Reserach Journal (Arts), XLV(1), 43-56.

Hussain, Ghulam (2019a), "Understanding Hegemony of caste in political Islam and Sufism in Sindh, Pakistan", Journal of Asian and African Studies, Vol. 54(5) 716-745. DOI: $10.1177 / 0021909619839430$.

Hussain, Ghulam (2019b), “Dalits are in India, not in Pakistan': Exploring the Discursive bases of the Denial of Dalitness under the Ashrafia Hegemony", Journal of Asian and African Studies. 1-27. DOI: 10.1177/0021909619863455.

Ilaiah, K. (2010). The Weapon of the Other: Dalitbahujan Writings and the Remaking of Indian Nationalist Thought. India: Pearson Education .

Kazuo, M. (2004). Toward the Formation of Sayyido-Sharifology:Questioning Accepted Fact. The Journal of Sophia Asian Studies(22), 87-103. 
Kolhi, B. M. (2014). Paracheen Lok: Ekweeheen Sadi Jey Aaeeney Mein (1st ed.). Hyderabad, Sindh, Pakistan: Himat Printers and Publishers.

Kolhi, V. (2011, August 23). 152nd Death Anniversary of A National Hero Defender of his

Motherland, Amar Rooplo Kohli. Retrieved from Veerji Kolhi:A Social Activist: http://veerjikolhi.blogspot.com/2011/08/152nd-death-anniversary-of-national.html

Kothari, Rita (2009) Unbordered Memories: Sindhi Stories of Partition, Penguine Groups, New Delhi.

Kumar, Vivek. 2016a. "Caste, Contemporaneity and Assertion." Economic and political weekly LI (50): 48-86.

Kumar, Vivek. 2016b. "How Egalitarian Is the Indian Sociology." Economic and Political Weekly LI (25): 33-39.

Kumbhojkar, S. (2012). Contesting Power, Contesting Memories: The History of the Koregaon Memorial. Economic and Political Weekly, 103-107.

Kundu, M. S. (2017, October 28). Et Tu 'Feminists'?: A response to the Kafila signatories. Roundtale India, Roundtable India. Retrieved October 28, 2017, from https://roundtableindia.co.in/index.php?option=com_content\&view=article\&id=9216\%3 Aet-tu-feminists-a-response-to-the-kafilasignatories \&catid $=119 \% 3$ Afeature $\&$ Itemid $=132$.

Levesque, J., \& Bui, C. (2014). Umar Marvi and the Representation of Sindh: Cinema and Modernity in the Margins. BioScope: South Asian Screen Studies, 5(2), 119-128.

https://doi.org/10.1177/0974927614547990

Margaret, M. S. (2012, March 8). Dalit Feminism. Roundtable India. Retrieved October 4, 2017, from https://roundtableindia.co.in/index.php?option=com_content.

Mal, P. (2000). Lok Sagar Ja Moti. Mirpurkhas: Parkari Audio Visual.

Manik (1992) Rujj aen Parada. Roshni Publications, Kandiaro. URL:

https://books.sindhsalamat.com/book.php?book_id=638. (accessed June 17 2019) 
Malkani, Mangharam. (1993). “Sindhi Nasar Ji Mukhtasir Tareekh”, Roshini Publications, Kandiaro.

Memon, Dr.Ghafoor (2002) 'Sindhi Adab jo Fikri Pasmanzar', Shah Latif Bhittai Chair.

Naik, C. D. (2010). Buddhism and Dalit:Social Philosophy and Traditions. Delhi: Kalpas Publications.

Nicolas, F. G. (2006). From Mongols to Mughals: Religious Violence in India 9th-18th Centuries. Pacific Northwest Regional Metting American Academy of Religion. Gonzaga University.

Ojha, Mangharam (1966) $\left(6^{\text {th }}\right.$ Ed, 2006). Puranon Parkar. Sindhi Adabi Board Paleejo, Rasool Bux (2012) 'Tanqeedi ain Takhleeki Adab'. Center for Peace \& Civil Society (CPCS).

Paleejo, Rasool Bux (2016, $1^{\text {st }}$ ed. 1978) ‘Sandi Zaat Hanjan’. Roshni Publications. Kandiaro. Raikes, C. S. ( 1856) (2009). Memoir on the Thurr and Parkur Districts of Sind:Selections from the Records of the Bomnbay Government. California: Sani Hussain Panhwar.

Rabbani, Ghulam (November, 2016). 'Where are the Pasmandas in Urdu short stories?' in Forwardpress. URL: https://www.forwardpress.in/2016/11/where-are-the-pasmandas-in-urdushort-stories/?fbclid=IwAR3GSzNjml20RUboi3tCnqytT4jWYaBkf59dkJIEFDZv32wYXiJKiYdkJo (accessed, June 16, 2019)

Sayed, G. M. (2013). Sindhu Desh. Reproduced by Sani Hussain Panhwar.

Sayed, GM (1952). Paigham-i-Latif. ( the online translated book),URL:

http://www.gmsyed.org/latif/book4-chap10.html. Accessed on, January 22, 2019 Sayed GM (1974) Sindh Ja Soorma. Naen Sindh Academy, Karachi. URL:

https://books.sindhsalamat.com/book.php?book_id=472. (accessed on June 6 2019) 
Shah, N. (2007a) Rin aen Rujj jo Itehas. Roshini Publication Kandiaro.

Shah, N (2007b) Jalawatan. Roshni Publications, Kandiaro.

Siraj (2009). Sindhi Language. Hyderbad: Sindhi Langage Authority.

Sripathi, A. (2017, October 25). Shit Has Hit the Fan With Raya Sarkar's Post On Sexual Harassers in Indian Academia. But Will It Just Stop There? Retrieved October 28, 2017, from The ladies finger: http://theladiesfinger.com/sexual-harassment-indian-academiafacebook/.

Trivedi, H. (2017). The Urdu Premchand and the Hindi Premchand. Revista Brasileira de Literatura Comparada, 19(30), 69-90.

Velaskar, P. (2012). Education for Liberation: Ambedkar's Thought and Dalit Women's

Perspectives. Contemporary Education Dialogue, 9(2), 245

271. https://doi.org/10.1177/097318491200900206.

Wajid, Muhammad (2017) Forced Religious Conversion of Hindus in Sindh (Myth or Reality):

A Case Study of Shahdadpur City (M.Phil. Thesis). International Islamic University, Islamabad, Pakistan.

Zelliot, E. (2011). Connected peoples: Pilgrimage in the structure of the Ambedkar movement. Contemporary Voice of Dalit, 4(1), 1-6. 